\title{
Dermoid cyst of the glans penis in a toddler
}

\author{
Ramnik V Patel, ${ }^{1,2}$ Dhaval Govani, ${ }^{3}$ Abid Qazi, ${ }^{4}$ Nadeem Haider ${ }^{5}$
}

1 Department of Paediatric Urology, University College London Hospitals NHS

Foundation Trust, London, UK ${ }^{2}$ Department of Paediatric

Urology, Great Ormond Street Children Hospital NHS Trust, London, UK

${ }^{3}$ Birmingham Medical School, Birmingham, UK

${ }^{4}$ Department of Paediatric Surgery, LGI, Leeds, UK ${ }^{5}$ Department of Paediatric Surgery, Christchurch Hospital, Christchurch, New Zealand

\section{Correspondence to} Ramnik V Patel, ramnik@doctors.org.uk

Accepted 28 April 2014

\section{DESCRIPTION}

Dermoid cysts are true hamartomas that occur when skin and skin structures become trapped during fetal development. The present paper describes a toddler with a dermoid cyst in glans penis which is extremely rare. We present a Caucasian toddler who had an important painless progressively increasing swelling of the glans penis dating back to early infancy. It was thought of a smegma cyst and when the foreskin became completely retractile at the age of 4 years, it became apparent that actually it was a lesion well below the covering epithelium of the glans penis in the midline (figure 1). On examination, a subepithelial well-circumscribed firm non-tender mass on the dorsal aspect of the midline of the glans penis covered by the fully retractile prepuce was present. There was no punctum, sinus or a fistula discharging pus or urine (figure 2). Laboratory tests, urine dipstick and microscopy and culture were negative. Ultrasound scan showed a well-defined cystic lesion with echogenic material filled in the lumen and a possibility of a dermoid cyst, a hamartoma or a sarcomatous slow-growing variant lesion was considered. At excisional biopsy a thick-walled cystic lesion in the subepithelial tissue of midline of glans was shelled out easily. His postoperative period was uneventful and at follow-up the wound has healed primarily. Cut section showed putty-like material. Histopathology examination revealed identification of a cyst having the epithelial lining and skin appendages (figure 3). A dermoid cyst of the glans penis in children has not been reported previously in the literature. ${ }^{1-3}$ It is congenital but may present later and mimic other lesions as was considered in our case. It may mimic a solid slow-growing sarcomatous lesion as the glans is compact and a tense cyst simulates a firm mass. Dermoid cyst of penis skin and not of the glans penis was described for

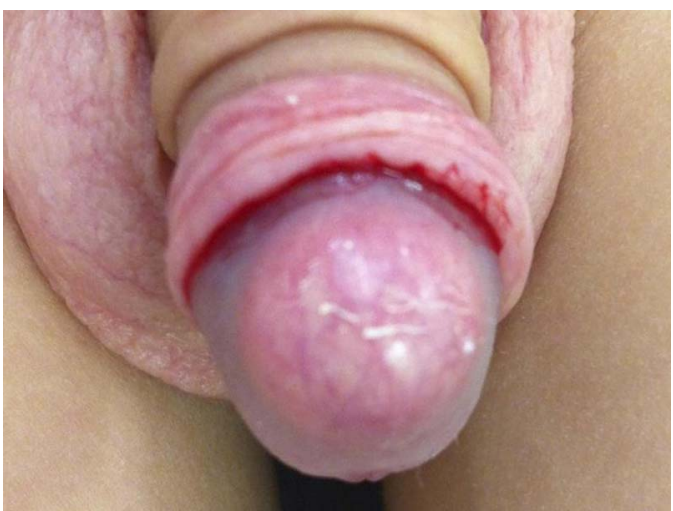

Figure 1 Clinical photograph showing top view of the dermoid cyst of the glans penis.

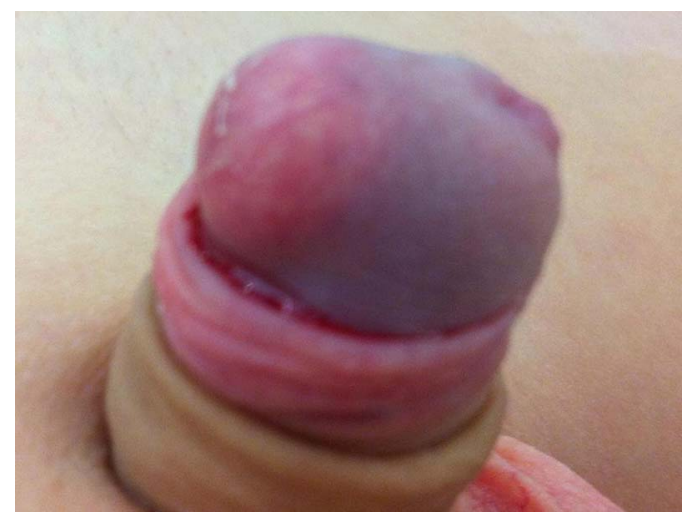

Figure 2 Side view of the glans dermoid cyst.

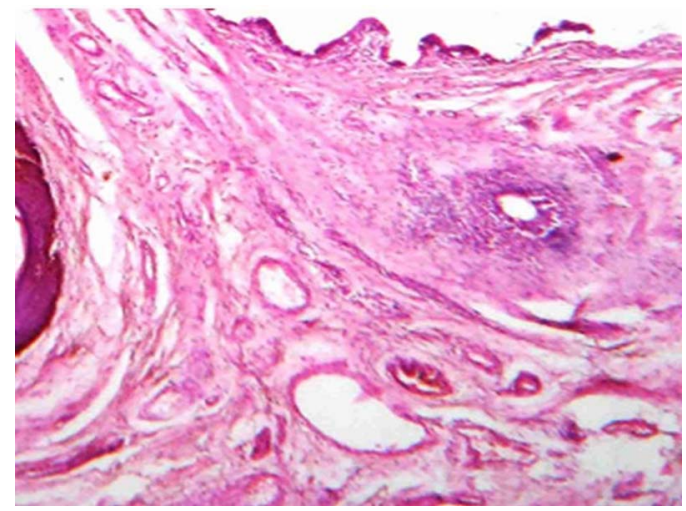

Figure 3 Microphotograph of the cyst showing cyst lining and skin appendages.

the first time in a young Caucasian man by Tomasini et al. ${ }^{4}$

\section{Learning points}

- Congenital lesions of the glans penis may present later on in life and may mimic a smegma cyst or hamartomatous lesions or sarcomatous ones clinically or on imaging.

- Midline masses on the glans or penile shaft should raise a suspicion of a dermoid or an epidermoid lesion in children.

- Surgical exploration and excision with gross appearance and cut section together with histopathology confirms the diagnosis and the prognosis is excellent.

Contributors All authors have actively participated in the preparation, editing and finalisation of this manuscript.

Competing interests None. 
Patient consent Obtained.

Provenance and peer review Not commissioned; externally peer reviewed.

\section{REFERENCES}

1 Patel RV, Marshall DM, Gannon C. Paediatric benign cystic mono-dermal testicular teratoma. BMJ Case Rep 2014;pii bcr-2013-202988.
2 Canali R, Angelini L, Castagnetti $M$, et al. Scrotal dermoid extending to the posterior urethra through a corpus cavernosum in a child. J Pediatr Surg 2012;

47:1618-21.

3 Larciprete G, Rossi F. Unusual dermoid cyst with surprise. J Minim Invasive Gynecol 2011;18:418.

4 Tomasini C, Aloi F, Puiatti P, et al. Dermoid cyst of the penis. Dermatology 1997:194:188-90.

Copyright 2014 BMJ Publishing Group. All rights reserved. For permission to reuse any of this content visit http://group.bmj.com/group/rights-licensing/permissions.

BMJ Case Report Fellows may re-use this article for personal use and teaching without any further permission.

Become a Fellow of BMJ Case Reports today and you can:

- Submit as many cases as you like

- Enjoy fast sympathetic peer review and rapid publication of accepted articles

- Access all the published articles

- Re-use any of the published material for personal use and teaching without further permission

For information on Institutional Fellowships contact consortiasales@bmjgroup.com

Visit casereports.bmj.com for more articles like this and to become a Fellow 